Bangladesh J. Bot. 44(2): 245-250, 2015 (June)

\title{
NPR1 GENE TRANSFORMATION AS ASSESSED BY GERM CELL IN SITU TRANSFORMATION PATHWAY INTO SIRAITIA GROSVENORII
}

\author{
Jing-Jian Li, XIN LiU, Bo Zhao AND Wen-Lan LI ${ }^{{ }^{*}}$ \\ Guangxi Institute of Botany, The Chinese Academy of Sciences, Guilin 541006, China \\ Key words: Siraitia grosvenorii, NPR1 gene, Germ cell, In situ transformation, Transgenosis
}

\begin{abstract}
NPR1 gene was transformed into Siraitia grosvenorii (Swingle) C. Jeffrey ex. A.M. Lu and Zhi Y. Zhang by germ cell in situ transformation. Ovary injection, cutting chapiter, and chapiter spreading treatments were applied in this study. The transgenic plants were selected using hygromycin screening and confirmed by PCR testing, genome integrated with NPR1 gene in transgenic plants was analyzed by Southern hybridization. Results showed that three treatments could produce transgenic plants. Some of the transgenic plants were selected for tobacco mosaic virus inoculation testing, which showed a higher level of resistance to tobacco mosaic virus than non-transgenic controls.
\end{abstract}

\section{Introduction}

Germ cell in situ transformation is a plant transgenic technique by which exogenous DNA can directly be transferred into plants (Zhou et al. 1983). Its main principle is that, after pollination, exogenous DNA injected into the ovary or passed along the pathway of pollen tube into the nucellus, entered to the embryonic sac and then integrated with the genome of zygote or early embryonic cells, and finally developed into transformed seeds. This method has high transformation efficiency, and acts on receptors that are spread throughout the organism. It provides a simple means of plant genetic transformation (Zhang et al. 2005, Liu et al. 2009).

Systemic acquired resistance (SAR) is a series of complex and effective defense mechanisms that can be gradually acquired as the plant struggles against pathogens. Recent research has demonstrated that non-expressor of pathogenesis-related gene-1 (NPR1) gene contributes considerable regulation to SAR (Tada et al. 2008). NPR1 is also a key regulator of downstream resistance genes, it regulates the occurrence of plant resistance across a broad spectrum of pathogens, conferring on plants resistance to bacterial and fungal pathogens (Dong 2004, Rochon et al. 2006, Yuan et al. 2007). Over-expression of NPR1 gene enhanced plant disease resistance but caused no other adverse reactions (Chern et al. 2005, Malnoy et al. 2007).

Siraitia grosvenorii (Swingle) C. Jeffrey ex. A.M. Lu and Zhi Y. Zhang belongs to Cucurbitaceae. It has a long history in Chinese traditional medicine and used as a sweetener in Chinese cuisine ( $\mathrm{Li}$ et al. 2004, Zhang and Li 2011). In conventional breeding, S. grosvenorii diseases can be important limiting factors affecting the yield in S. grosvenorii production (Cai et al. 2011). In the present study, NPR1 gene was transferred into S. grosvenorii by germ cell in situ transformation in the hope of obtaining transgenic plants. It may allow breeders to offer elite resistant varieties and provide a new technical reference for the genetic engineering of $S$. grosvenorii.

*Author for correspondence: <283223173@qq.com>. ${ }^{1}$ College of Life Science, State Key Laboratory for Conservation and Utilization of Subtropical Agro-bioresources, Guangxi University, Nanning 530004, China. 


\section{Materials and Methods}

The binary vector used in this experiment was pCaMVNPR (Fig. 1), consisted of NPR1 gene, obtained from Arabidopsis thaliana, under the control of CaMV 35S promotor with a CaMV 35S terminator as described in earlier report (Qin et al. 2005). Green S. grosvenorii plants were provided by S. grosvenorii plant base of Lingui County, Guilin City, Guangxi, China. A large amount of plasmid DNA was extracted using the alkaline lysis method (Osborne et al. 2005).

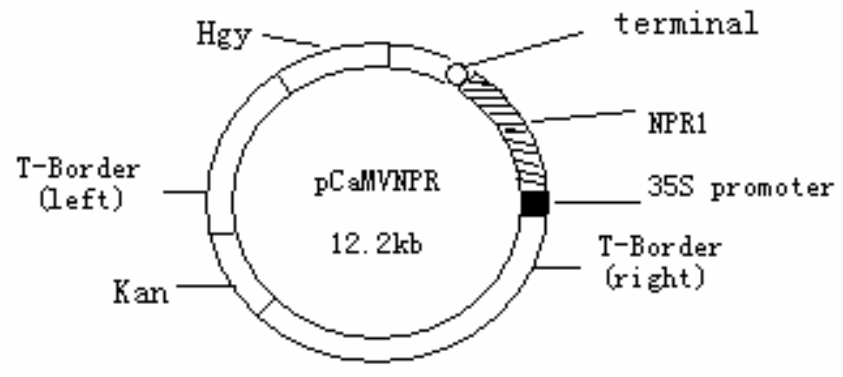

Fig. 1. Structure of binary vector $p C a M V N P R$.

S. grosvenorii plants were grown in soil-based compost under natural conditions (Guilin China). To prevent pollen contamination, the female flower buds were bagged before flowering. Three treatments of Germ cell in situ transformation were performed in this study, they are ovary injection, cutting chapiter, and chapiter spreading. Ovary injection was performed in 4, 8, 12, 16, and $20 \mathrm{hrs}$ after artificial pollination, plasmid DNA was injected into ovary by microinjector. Cutting chapiter was performed in $2 \mathrm{hrs}$ after artificial pollination, $1 / 3$ of the length of stigma was cut out by using a sterile blade, plasmid DNA was dropped into the incision by glass capillary tube. Chapiter spreading accomplished by dropping pollen onto stigma directly, pollen was treated with a solution of plasmid DNA and mannitol before use. After each treatment, we measured fruit set as the percentage of flowers that produced fruit, and harvested first generation seeds when all fruits had matured.

The selection antibiotic hygromycin was used in the culture medium to optimize the level of selection for transgenic seedlings. Non-transgenic seeds were budded on selection medium with different concentrations of hygromycin to determine its resistance. Seven concentration gradients of hygromycin were set, including $0,5,10,15,20,25$, and $30 \mathrm{mg} / \mathrm{l}$, and the experiment was repeated three times with similar results. According to the results of hygromycin sensitivity experiment, the first generation seeds were budded on the selection medium containing $15 \mathrm{mg} / \mathrm{l}$ hygromycin. Three weeks later, normal resistant seedlings were transferred to MS without hygromycin and incubated at $25 \pm 2{ }^{\circ} \mathrm{C}$ under a light at 1500 lux for $16 \mathrm{hrs}$ per day. Resistant seedlings that grew to a height of $8-10 \mathrm{~cm}$ were transplanted to soil under greenhouse conditions for further analysis.

Total genomic DNA was isolated from young leaves of transgenic and non-transgenic plants using the cetyl trimethyl ammonium bromide (CTAB) method (Osborne et al. 2005). Upstream and downstream primers were designed according to the sequences of the NPR1 gene (Upstream primer: 5'-TCG GAA CCT GTT GAT GGA CAC-3' and downstream primer: 5'-GTG GCT CCT TCC GCA TCG C-3'). The PCR reaction system contained $1 \mu$ template DNA, $2 \mu 1$ upstream and downstream primers, $0.5 \mu \mathrm{ldNTP}, 3 \mu 110 \times$ buffer, $0.5 \mu \mathrm{l}$ Taq enzyme, and distilled water to a total volume of $25 \mu \mathrm{l}$. The PCR amplification program began with predenaturation at $95^{\circ} \mathrm{C}$ for 5 min followed by 35 cycles of denaturation at $94^{\circ} \mathrm{C}$ for $30 \mathrm{~s}$, annealing at $55^{\circ} \mathrm{C}$ for $30 \mathrm{~s}$, and 
extension at $72^{\circ} \mathrm{C}$ for $3 \mathrm{~min}$; after which the reaction mixture was maintained at $72^{\circ} \mathrm{C}$ for $10 \mathrm{~min}$, and the reaction was quenched at $4^{\circ} \mathrm{C}$. The PCR products were detected using electrophoresis on $1 \%$ agarose gel. PCR positive plants were subjected to further Southern hybridization to confirm transgene integration. Total DNA extracted from leaves of the transgenic and non-transgenic $S$. grosvenorii plants were fully digested by HindIII and separated by $0.8 \%$ agarose gel electrophoresis. The DNA fragment was transferred to a positively charged nylon membrane. An NPR1 gene fragment was used as a probe, it was obtained by PCR amplification using pCaMVNPR1 as the template and labeled with digoxigenin. Pre-hybridization, hybridization, membrane washing, and immunological detection were carried out successively accordance to Sambrook et al. (2002).

For inoculation testing, leaves of $S$. grosvenorii infected with tobacco mosaic virus were immersed in phosphate buffer (PBS, pH 7.4) at a ratio of $1: 10$ (Leaf mass : buffer volume). They were then ground with a mortar and pestle into fine powder in an ice bath. The supernatant was collected by centrifugation at $4000 \mathrm{rpm}$, and used as a source of inoculation toxicant. Southern blot positive transgenic plants were inoculated at random according to virus sap rub inoculation method (Du et al. 2004). The phenotypes of the inoculated plants were noted at different post inoculation times.

\section{Results and Discussion}

Hygromycin had a significantly inhibition on seed germination and radicle growth. The germination rate gradually decreased as the hygromycin concentration increased. Seeds germinated and grew normally in the culture medium without hygromycin. However, in the culture medium containing $5 \mathrm{mg} / \mathrm{l}$ hygromycin, only a few seeds germinated but with a short time lag, and finally they stopped growing when the radicles reached $0.1 \mathrm{~cm}$ in length. When the concentration of hygromycin was increased to $10 \mathrm{mg} / \mathrm{l}$, only a few seeds germinated, but failed to grow. When the concentration of hygromycin reached $15 \mathrm{mg} / \mathrm{l}$, there was no visible sign of germination. In this way, $15 \mathrm{mg} / \mathrm{l}$ of hygromycin was confirmed as the optimal concentration for resistance selection (Table 1).

Table 1. Effects of hygromycin on seed growth.

\begin{tabular}{lccc}
\hline $\begin{array}{l}\text { Concentration of } \\
\text { hygromycin }(\mathrm{mg} / \mathrm{l})\end{array}$ & $\begin{array}{c}\text { Total number of } \\
\text { seeds }\end{array}$ & $\begin{array}{c}\text { Number of budding } \\
\text { seeds }\end{array}$ & $\begin{array}{c}\text { Normal budding } \\
\text { rate }(\%)\end{array}$ \\
\hline 0 & 100 & 93 & 93 \\
5 & 100 & 10 & 0 \\
10 & 100 & 4 & 0 \\
15 & 100 & 0 & 0 \\
20 & 100 & 0 & 0 \\
25 & 100 & 0 & 0 \\
30 & 100 & 0 & 0 \\
\hline
\end{tabular}

Three transformation treatments were used in this experiment. The results of ovary injection treatment showed that injection performed at different time after pollination was caused in different transformation rates, as it is showed in Table 2, we could conjectured that the pollination process of S. grosvenorii was similar to that of watermelon (Liu et al. 1994). At $12 \mathrm{hrs}$ after pollination, the transformation rate was $11.5 \%$ (Table 2). Molecular detection results showed that cutting the chapiter and chapiter spreading had a significantly lower transformation rate than ovary 
injection. Their transformation rates were 2.9 and $1.3 \%$, respectively (Table 2). Based on transformation efficiency, the ovary injection treatment was found to be the best, 12 hours after pollination was confirmed to be the optimal injection time for transformation.

Table 2. Transformation results of germ cell in situ transformation.

\begin{tabular}{lccccccc}
\hline Treatment & $\begin{array}{c}\text { Time of injection } \\
\text { (hr after } \\
\text { pollination) }\end{array}$ & $\begin{array}{c}\text { Female } \\
\text { flowers }\end{array}$ & $\begin{array}{c}\text { Fruit } \\
\text { set } \\
(\%)\end{array}$ & $\begin{array}{c}\text { Number of } \\
\text { harvested } \\
\text { seeds }\end{array}$ & $\begin{array}{c}\text { PCR } \\
\text { positive } \\
\text { plants }\end{array}$ & $\begin{array}{c}\text { Southern blot } \\
\text { positive } \\
\text { plants }\end{array}$ & $\begin{array}{c}\text { Transfor- } \\
\text { mation rate } \\
(\%)\end{array}$ \\
\hline Ovary injection & 4 & 60 & 10.0 & 91 & 3 & 3 & 3.3 \\
& 8 & 60 & 26.7 & 255 & 12 & 12 & 4.7 \\
& 12 & 60 & 36.6 & 269 & 31 & 31 & 11.5 \\
Cutting chapiter & 16 & 60 & 41.7 & 352 & 5 & 5 & 1.4 \\
Chapiter spreading & 20 & 60 & 48.3 & 476 & 0 & 0 & 0.0 \\
\hline
\end{tabular}

Resistant plants were selected from three treatment groups using hygromycin and subjected to PCR detection and then electrophoresis. The PCR products of plasmid DNA ( $p C a M V N P R)$ and non-transgenic plants served as control samples. Specific bands amplified from genomic DNA of transgenic plants were consistent with bands amplified from positive plasmid DNA (1.1 kb), but the non-transgenic plants did not produce any bands (Fig. 2). Transformed plants confirmed to be

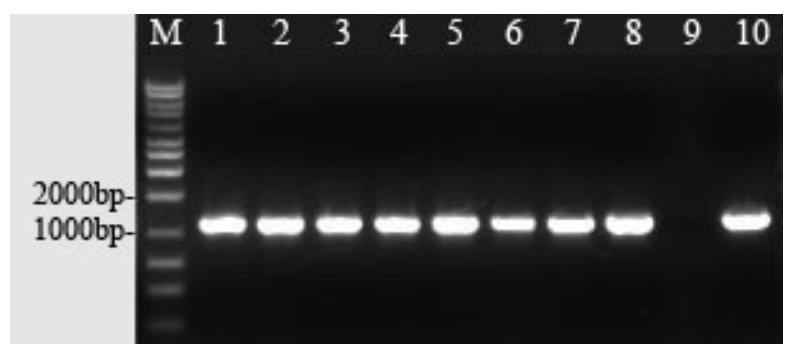

Fig. 2. Results of PCR analysis. Lane M: DNA molecular size markers ( $\lambda$ DNA/Hind III + EcoRI), lanes 1 - 8: DNA isolated from detected transgenic plants, lane 9: DNA isolated from non-transgenic plants, lane 10: Plasmid ( $p C a M V N P R$ ).

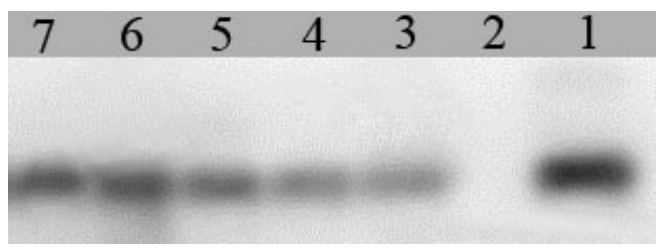

Fig. 3. Southern blot analysis of PCR positive transgenic plants. Lane 1: Probe, lane 2: DNA isolated from non-transgenic plants, lanes 3 - 7: DNA isolated from putative transgenic plants.

positive under PCR detection were subjected to further Southern blot analysis to confirm the integration and the copy number of transgenes in transgenic S. grosvenorii. The results showed that the non-transformed plants produced no hybridization signals, but all the transformed plants did (Fig. 3). This indicated that the NPR1 gene was integrated into the S. grosvenorii genome. 
Inoculation testing and field observation showed that transgenic plants had considerably high and stable horizontal resistance to tobacco mosaic virus, and grew very well. Contrarily, the nontransgenic plants exhibited typical mosaic virus disease symptoms 7 - 10 days after inoculation (Fig. 4). These observations clearly confirm that NPR1 expression can provide significant protection against tobacco mosaic virus, all of these phenotype have been found to be correlated with the expression of NPR1 (Vilas et al. 2010, Vijayan and Kirti 2012).

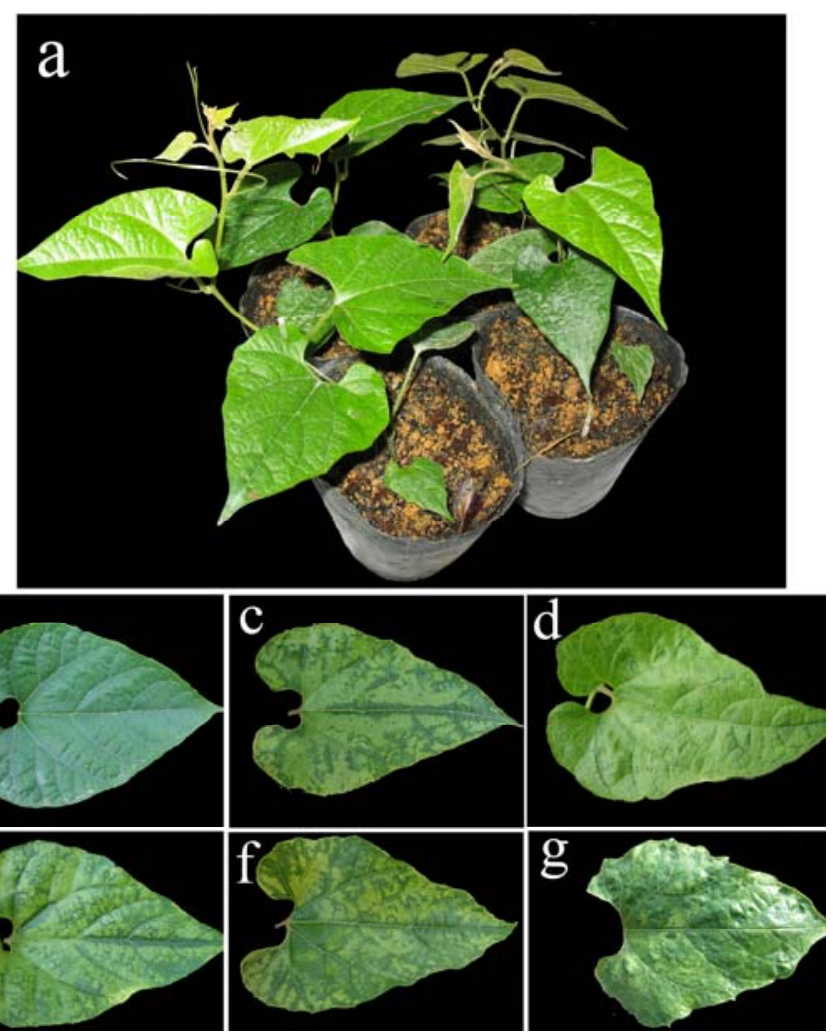

Fig. 4. Tobacco mosaic virus assay of transgenic and the non-transformed controls. a. Young transgenic plants before inoculation with the tobacco mosaic virus, b. The leaf of a transgenic plant after inoculation with tobacco mosaic virus, $\mathrm{c}, \mathrm{d}$, e, $\mathrm{f}$ and $\mathrm{g}$ belong to non-transformed control plants after inoculation with tobacco mosaic virus.

In summary, the results present in this study confirm that expression of NPR1 in $S$. grosvenorii leads to enhanced resistance to tobacco mosaic virus, the transformants appeared normal in their growth and development. These results also suggest that Germ cell in situ transformation provide an effective tool to obtain transgenic plant, it may be applied to any flowering plants so long as the plant's flowering habits, flower structure, pollination and fertilization time are known. Regardless, we have successfully produced transgenic plants of $S$. grosvenorii by transforming NPR1 gene via Germ cell in situ transformation. Our work may provide technical reference for $S$. grosvenorii and other flowering plants in genetic engineering breeding. 


\section{Acknowledgements}

This research was funded by the Natural Science Foundation of Guangxi China (0728096), Special Categorized Karst Plants Garden Construction (11217028). The authors gratefully thank the Siraitia grosvenorii plant base of Lingui County, Guilin City, Guangxi, China for providing green S. grosvenorii plants.

\section{References}

Chern MS, Fitzgerald HA, Canlas PE, Navarre DA and Ronald PC 2005. Overexpression of a rice NPR1 homolog leads to constitutive activation of defense response and hypersensitivity to light. Mol. Plant Microbe. Interact. 18: 511-520.

Cai JH, Qin BX, Yu YB and Liu ZM 2011. Virus identification of luohanguo mosaic diseases. Guangxi Sci. 8(1): 66-69.

Dong X 2004. NPR1, all things considered. Curr. Opin. Plant Biol. 7: 547-552.

Du GY, Wang XF and Zhou GH 2004. Digoxigenin-labelled cDNA probes for the detection of Tobacco mosaic virus, cucumber mosaic virus and Potato virus Y. Acta. Phytopathol. Sin. 34(1): 75-79.

Liu M, Yang J, Cheng YQ and An LJ 2009. Optimization of soybean [Glycine max (L.) Merrill] in planta ovary transformation using a linear minimal GUS gene cassette. J. Zhejiang Univ-Sc. B 10(12): 870-876.

Li F, Li DP, Jiang YP and Zhang HR 2004. Siraitia grosvenorii cultivation and exploitation. China Forestry Publishing House Press, Beijing, China.

Liu JP, XU YY and LIU Y 1994. Studies on double fertilization in watermelon. China Watermelon 2: 8-9.

Malnoy M, Jin Q, Borejsza Wysocka EE, He SY and Aldwinckle HS 2007. Over expression of the apple M pNPR1 gene confers increased disease resistance in malus $\times$ domestica. Mol. Plant Microbe Interact. 20(12): 1568-1580.

Osborne F, Brent R and Kingstone 2005. Current protocols in molecular biology. Science press, Beijing, China.

Qin XM, Li WL, Zhang LZ, Li HM and Tan PS 2005. Cloning and expression vector construction of Arabidopsis NPR1 gene. Guihaia 25(1): 58-61.

Rochon A, Boyle P, Wignes T, Fobert PR and Despres C 2006. The coactivator function of Arabidopsis NPR1 requires the core of its $\mathrm{BTB} / \mathrm{POZ}$ domain and the oxidation of C-terminal cysteines. Plant Cell 18(12): 3670-3685.

Sambrook J, Fritsch EF and Maniatis T 2002. Molecular Cloning: A Laboratory Manual. Science press, Bejing, China.

Tada Y, Spoel SH, Pajerowska Mukhtar K, Mou ZL, Song JQ, wang C, Zuo JR and Dong XN 2008. Plant immunity requires conformational charges of NPR1 via S-nitrosylation and thioredoxins. Sciences 32: 952-956.

Vilas PK, Vinod MC, LeAnne AB, Alois SJ and Keerti SR 2010. Resistance against various fungal pathogens and reniform nematode in transgenic cotton plants expressing Arabidopsis NPR1. Transgenic Res. 19: 959-975.

Vijayan S and Kirti PB 2012. Mungbean plants expressing BjNPR1 exhibit enhanced resistance against the seedling rot pathogen, Rhizoctonia solani. Transgenic Res. 21: 193-200.

Yuan YX, Zhong SH, Li Q, Zhu ZR, Lou YG, WangLY, Wang JJ, Wang WY, Li QL, Yang DL and He ZH 2007. Functional analysis of rice NPR1-like genes reveals that OsNPR1/NH1 is the rice orthologue conferring disease resistance with enhanced herbivore susceptibility. J. Plant Biotechnol. 5: 313-324.

Zhou GY, Weng J, Zeng YS, Huang JQ, Qian SY and Liu GL 1983. Introduction of exogenous DNA into cotton embryos. Meth. Enzymol. 101: 433-481.

Zhang YS, Zhai SM, Yang AF and Zhang JR 2005. Maize transformation via pollen tube pathway and the inheritance of transgene in progen. High Tech. Commun. 1(2): 202-206.

Zhang H and Li XH 2011. Research Advance of Pharmacological Effects and Toxicity of Siraitia grosvenorii (Swingle) C. Jeffrey. Chinese Agric. Sci. Bull. 27(5): 430-433. 